cancer rate, corrected for the increasing age of the population, rose slightly to 1,003 per million, but was still below the levels reached in 1928 and 1929 . A new feature of the review is the tabulation of a 'comparability factor' for each separate town and rural district, which shows at a glance whether the distribution of persons by age and sex in the population of that area would lead to the expectation of a death rate above or below that of the country as a whole, and makes it possible to correct the death rate by a simple multiplication for valid comparison with that of any other area similarly corrected. After correcting in this way, the administrative County of London and the south eastern counties of Kent, Surrey, Sussex, Hampshire, Isle of Wight and Berkshire gave a combined mortality rate after correction only 84 per cent of that of the country as a whole, compared with 113 per cent for the north of England, namely, Durham, Northumberland, Cumberland, Westmorland, Yorkshire, Lancashire and Cheshire.

\section{Archæological Investigation under the Soviets}

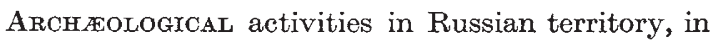
which the work of the Historical Museum of Moscow has been reinforced by the co-operation, financial and other, of museum authorities in the United States, have produced results of no little historical importance. Archæologists on the staffs of the various Russian museums are now engaged, according to a report from the Moscow correspondent of the Observer in the issue of October 27, in examining material brought in by expeditions to the Crimea, Kazakstan in Central Asia, the Georgian Republic in the Caucasus and the Ural Province. From the Crimea comes further evidence relating to Neanderthal man in the form of stone implements from a settlement site - not a cave-on the Katcha River, while in the neighbouring village of Pychka rockpaintings in red, depicting battle scenes, were discovered, which are attributed to a pre-Scythic culture of the third millennium B.C. The expedition of the Historical Museum to Kazakstan was occupied in excavating a site of the Bronze Age, on which a communal hut, measuring twenty-five metres in length, has been uncovered, as well as an altar about which were the charred bones of domestic animals, vessels containing the remains of food and bone cubes, which are said to resemble modern dice. In the Caucasus, cave deposits were examined, which yielded a number of flint implements of the palæolithic age.

\section{Illuminating Engineering}

In his presidential address to the Illuminating Engineering Society, delivered on October 8, Mr. A. W. Beuttell took an optimistic view of the future of illuminating engineering. $\mathrm{He}$ based his claim on the inevitable demand for more artificial light which must approximate more and more to daylight. At the moment, the cost of this light is prohibitive, and the problem is to produce more light whilst using no more energy. The keeping low of energy costs will increase the cost of equipment. It is now realised that having incandescent metals near their melting point does not give the solution. On the other hand, vapour discharge lamps, although we are only at the threshold of these fields of discovery, whilst giving cheaper light, do not give white light. The question is now being thoroughly explored. The disturbance of electrons causing light is produced by heat, but at present much energy is lost in the nonvisible spectrum. This problem is of great importance owing to the future great demand for light and the well-defined field with which we have to deal, and the fact that the production of light is based on the fundamental principles which physicists study. In considering the production and use of light, the psychological aspect has also to be considered. $\mathrm{Mr}$. Beuttell expressed the view that in both the physiological and psychological processes concerning light, cause and effect hold good. Whilst we are learning rapidly, it is necessary that specialists should pool their knowledge.

\section{The Internal Combustion Engine and its Fuel}

ON October 9, Mr. H. R. Ricardo received the Melchett Medal of the Institute of Fuel, and after the presentation delivered his Melchett Lecture on the "Progress of the Internal Combustion Engine and its Fuel". This progress he characterised as one of the most startling developments of the last fifty years, and now, he said, more than eighty per cent of the total power output of prime movers is based on petrol. He traced the development of the views held on the cause and character of the phenomenon of 'engine knock' and the formulation of the wellknown method of evaluating knock-tendency' by means of the variable compression engine. The value of aromatic hydrocarbons was established by this machine and later the practice of rating fuel by an 'octane-number'. The production of fuels with high 'octane-numbers' has permitted the use of higher compression ratios with consequent greater engine efficiency, culminating in the 60 horse-power per litre attained by the Schneider engines. Further increase in the octane-number of petrols is not anticipated, nor the use of supercharging in pleasure cars. The Diesel engine is displacing the petrol engine in heavy commercial vehicles, and will continue to do so even at the same cost of fuel per gallon, owing to the 70 per cent advantage in the figure of miles per gallon.

\section{The King's Fund Miniature Hospital}

$I_{N}$ order to make known more widely the great work of the voluntary hospitals, Mr. Saxe Wyndham in 1929 suggested to the King Edward's Hospital Fund for London that a model of a modern hospital, complete in its smallest details, would be likely to arouse the interest of the public and so help the King's Fund. The Propaganda Committee of the Fund decided to undertake this work, and a design for the model was commenced by the late Mr. Percy Adams, and completed after his death by Mr. Lionel Pearson. At first, there was some difficulty in obtaining the necessary funds, but eventually Messrs. 
Humphreys, Ltd., of Knightsbridge, generously undertook the responsibility, and a number of other firms collaborated in the construction and equipment. The model is to a scale of one sixteenth of full size, and includes adults' and children's wards, complete with bathrooms, lavatories and sink rooms, and with circular solarium at the end, operating theatres, X-ray apparatus, staircases and working electric lift, board room and kitchen, balconies and garden, together with figures of doctors, nurses and patients. The work was executed by a staff of skilled craftsmen, and so far as possible every detail essential to a building of this kind has been reproduced in the model-furniture, bedding, screens, radiators and others too numerous to mention. The model is on view until further notice at British Industries House, Hereford House, Oxford Street, London.

\section{Agricultural and Horticultural Research}

THE year 1934, coming after a period of monetary anxiety, brought financial stability to the National Fruit and Cider Institute and Research Station at Long Ashton, Bristol. This gratifying state of affairs has allowed the completion, or further prosecution, of several important pieces of investigational work. Some results of these are published in the annual report of the Station for 1934 (Long Ashton, pp. 312, July 1935). A foreword by Prof. B. T. P. Barker, the director, outlines the administrative changes of the organisation, and also of the Berkeley Square Advisory Centre, Bristol. The principal contributions of research results are three papers on the maturity of fruit by Dr. J. C. Hinton (NATURE, Oct. 26, p. 687), whilst numerous studies of pests and plant pathology have been prosecuted. The cider investigations include a consideration of the suitability of various containers for apple juice, the role of pectin in cidermaking, experiments on clarification of the juice, and preservation with sulphur dioxide. A soil survey of the Teart Land areas of Somerset is also being made.

\section{Television in Australia}

Baird Television, Lto. announces that as the result of negotiations with the Australian Radio Manufacturers' Patents Association, Ltd., of Sydney, the Association has been appointed the exclusive representatives in Australia of the Baird Company, both for the construction and operation of television transmitting stations and the manufacture of television receivers under the Baird patents. The Australian Radio Manufacturers' Patents Association, Ltd. is composed of a majority of the leading radio manufacturers throughout the Commonwealth of Australia, and they propose to develop television as an adjunct to sound broadcasting. Experimental transmitters will, it is expected, be erected in Sydney and Melbourne in the near future, with the view of providing ultimately a commercial high-definition television service.

\section{Louis Lumière Celebrations}

A Meeting to celebrate the fortieth anniversary of the invention of the cinematographe by Louis and
Auguste Lumiere will be held in the Hall of the Sorbonne, Paris, on November 6 at 9 p.m. The meeting will be held under the presidency of M. Mario Roustan, Minister of Education; and M. Albert Lebrun, President of the Republic, will be present. Among the discourses will be one given by Prof. C. Fabry, professor of physics in the Sorbonne and president of the French Society of Photography and Cinematography. During the celebrations, certain films made in 1894, and colour photographs of 19071935, will be exhibited. Further information can be obtained from the Secrétaire Général, 11 Avenue Casimir, Asnières (Seine).

\section{Awards of the Institution of Civil Engineers}

THe following awards of the Institution of Civil Engineers have recently been made for papers read and discussed at ordinary meetings : a Telford Gold Medal to B. M. Hellstrom (London); a Telford Premium jointly to F. W. D. Davis (London) and William Mackenzie (Hull); a Telford Premium to G. L. Groves (London) ; a Telford Premium jointly to C. Seager Berry (Baldock) and A. C. Dean (Manchester); a Telford Premium to E. J. Buckton (London); a Telford Premium to W. J. H. Rennie (Singapore); a Telford Premium and the Coopers Hill War Memorial Prize to A. W. H. Dean (New Delhi); a Telford Premium and the Indian Premium to M. G. Platts (Madras) ; a Telford Premium jointly to J. A. K. Hamilton (Cleveland, York) and J. Tudor Graves (Middlesbrough); a Telford Premium to Alexander Gray (St. John, Canada) ; a Trevithick Premium to George Mclldowie (Newcastle, Co. Down); a Trevithick Premium jointly to W. T. W. Miller (Sheffield) and R. J. Sargant (Sheffield); a Manby Premium to M. A. Ravenor (London); a Crampton Prize jointly to V. F. Bartlett (London) and W. H. Cadwell (Mellor, Derbyshire). For papers published without discussion as 'Selected Engineering Papers' : a Telford Premium to T. H. Hopkins (Bromley, Kent); a Telford Premium jointly to Prof. E. G. Coker (London) and G. P. Coleman (London); a Telford Premium to Ralph Poole (Bradbury, Cheshire); a Telford Premium to W. H. Weston (Glasgow); a Telford Premium to C. G. Watson (London). For papers read at students' meetings: the James Forrest Medal and a Miller Prize to James Halliday (Dunbar); Miller Prizes to R. S. Cogdon (Sunderland), Geoffrey Wood (London), R. G. Rowbotham (Buenos Aires), G. R. Coles (St. Albans, Herts) and J. L. Matheson (Stafford). The Charles Hawksley Prize has been awarded to Frank W. Curry (London).

\section{Announcements}

AT the annual statutory meeting of the Royal Society of Edinburgh held on October 28 the following council was elected: President: Prof. D'Arcy Wentworth Thompson; Vice-Presidents : Prof. C. G. Darwin, Prof. R. A. Sampson, Principal O. Charnock Bradley, Prof. P. T. Herring, the Marquis of Linlithgow and Prof. E. B. Bailey; General Secretary : Prof. J. H. Ashworth; Secretaries to Ordinary 